\section{ま と め}

埼玉県浦和市三室にあるサギのコロニーで 1975 年か ら 78 年の間にみられた大量の落鳥拉よび死亡例につい て細菌学的検查を行なったところ, 次のような成績をえ た.

1）死亡サギおよび落鳥サギから高率にS. typhimurium が検出され, 細菌学的ならびに病理学的所見から, 本事 例はサギのサルモネラ感染症と診断した.

2）分離した S. typhimurium は同一生物型を示し，人 をとりまく環境から検出されるるのとは異なることか ら, このコロニー内で種属間の感染症を起こしたものと 推察した.

3）排菌サギに対するクロラムフェニコールの治療効 果が期待できるが，完全な除菌楁よび再感染の点でその 防除は困難であると思方孔る.

本調查にあたり，ご協力をいただいた埼玉県環境部自
然保護課, 放射線医学研究所山極順二氏, 開業獣医師 池谷奉文氏拉よび三室のコロ 一管理者 武中 尚氏に 深謝します。

$$
\text { 文献 }
$$

1）浅木正義, 岡 千晶, 佐藤儀平 : Jap. J. vet. Scie., 38, 521 522 (1976).

2) Duguid, J.P., Anderson, E.S., Alfredson, G.A. \& OLD, D.C.: J. Med. Microbiol., 8, 149 166 (1975).

3) Faddoul, G.P. \& Fellows, G.W.: Avian Disease, 10, 377 381 (1965) 89 94 (1966).

4) 石山俊次, 上田 泰, 桑原章吾, 小酒井 望, 古屋 暁一, 紺野昌俊, 藤井良和: Chemotherapy, 16, 98 $\sim 99$ (1968).

5) Petrak, M.L.: Disease of Cageand Aviary Bird, 357 372, Philadelphia, Lea \& Febiger (1969).

6) 佐藤儀平, 石黒直隆, 浅木正義, 岡 千晶, 河西 勉, 井上風已 : Jap. J. vet. Scie., 39,609 617 (1977).

\title{
山羊に打ける実験的低 $\mathrm{Ca}$ 血症に関する研究
}

$$
\text { 姜正夫* 本好茂一** }
$$

(昭和 54 年 9 月 21 日受理)

Studies on Experimental Hypocalcemia in Goats

Chung Boo Kang and Shigekatsu Motoyoshi (Faculty of Agriculture, University of Tokyo, Bunkyo-ku, Tokyo 113 and Nippon Veterinary and Zootechnical College, Musashino, Tokyo 180)

\section{SUMMARY}

Experimental hypocalcemia was induced in normal goats by intravenous administration with various concentrations of $\mathrm{Na}_{2}$-EDTA solution.

1. Progressive depression of reflexes and body temperature, paresis, and cardiac arrest were observed in two groups administered with $4 \%$ and $8 \%$ EDTA, respectively. They were not observed within 240 minutes after administration with $2,2.5$, or $3 \%$
EDTA.

2. The tissue calcium concentration was lower in all the goats which died after EDTA administration than in the normal one.

3. The tissue calcium concentration became much lower in the cerebral cortex than in the rectus femoris muscle after EDTA administration.

\section{緒言}

細胞外液, とくに血中 $\mathrm{Ca}$ 濃度はその恒常性維持機構 により一定した範囲内に保たれている. 生体に怙いてカルシウムイオン $\left(\mathrm{Ca}^{++}\right)$は組織細胞の

* 東京大学農学部 (東京都文京区弥生1-1-1)

** 日本獣医畜産大学 (東京都武蔵野市境南町 1-7-1)
種々の生理的機能を調節する因子として重要な役割をは たしている，家畜に抹ける種々の低 Ca血症のように血 中濃度の著しい低下をきたしている状態では組織内 $\mathrm{Ca}$ の動態にる変動をもたらすことが十分考兄られる.

低 $\mathrm{Ca}$ 血症の成因関する研究は多方面から数多くな されている ${ }^{2,5,7,10 \sim 14)}$ が，その典型的症状の発現機序に 関する研究はきわめて少ない,

日獣会誌 $32 \quad 685 \sim 689$ (1979) - $685-$ 
山羊における実験的

Ethylendiaminetetraacetate はヒトの副甲状腺機能検 查法に用いられて抢り, 血清カルシウムイオンと速やか 飞結合し，これを低下させるのでこの作用を利用して， 山羊に対して実験的に低 $\mathrm{Ca}$ 血症を作製し, 低 $\mathrm{Ca}$ 血症 に対応して発現する一連の生体反応を組織内 $\mathrm{Ca}$ 変動と 併せて検索した結果，二，三の知見を得たので報告する.

\section{実 験 材 料 および方 法}

\section{1. 供 試 動 物}

実験に供した山羊は表 1 に示した計 17 頭(雌 6 ,雄 11 ) の成熟在来種山羊である. これは本学附属牧場で生産さ れ, 入手後 1 週間以上にわたる観察でとくに運動器系に 異常が認められなかったものである.

飼育期間中の飼料としては, ヘイキューブと配合飼料 が主体でとくに Ca 剤の給与は行なっていない.

表 1 供試動物, $\mathrm{Ca}$ 検体採取部位および死亡時間

\begin{tabular}{|c|c|c|c|c|c|c|c|}
\hline 山羊 & 体重 & & ETA & & 検 体 採 & 取 & 死時 \\
\hline No. & $(\mathrm{kg})$ & & $(\%)$ & 血漿 & 死後組織 & 生検組織 & (分) \\
\hline 1 & 19 & 雌 & 2 & $\circ$ & & & - \\
\hline 2 & 28 & "I & 2.5 & $\circ$ & & & - \\
\hline 3 & 30 & "I & 3 & $\circ$ & & & - \\
\hline 4 & 17 & "I & 4 & $\circ$ & & & 147 \\
\hline 5 & 13 & 雄 & 4 & $\circ$ & $\circ$ & & 210 \\
\hline 6 & 17 & "I & 4 & $\circ$ & & & 180 \\
\hline 7 & 23 & 雌 & 4 & $\circ$ & $\circ$ & $\circ *$ & 120 \\
\hline 8 & 50 & 雄 & 4 & & $\circ$ & & 435 \\
\hline 9 & 63 & "I & 4 & & $\circ$ & & 636 \\
\hline 10 & 14 & "I & 8 & $\circ$ & & & 39 \\
\hline 11 & 14 & "I & 8 & $\circ$ & $\circ$ & & 24 \\
\hline 12 & 14 & "I & 8 & $\circ$ & $\circ$ & & 26 \\
\hline 13 & 17 & "I & 8 & $\circ$ & $\circ$ & & 28 \\
\hline 14 & 29 & 雌 & 8 & $\circ$ & $\circ$ & & 90 \\
\hline 15 & 43 & 雄 & 8 & $\circ$ & $\circ$ & $\circ * *$ & 45 \\
\hline 16 & 19 & "I & 8 & $\circ$ & $\circ$ & $\circ * *$ & 56 \\
\hline 17 & 58 & "I & & $\circ$ & $\circ$ & & - \\
\hline
\end{tabular}

。*...大腿直筋 。**...大腿直筋と大脳皮質 死後組織の採取部位は表 2 に示す

2. $\mathrm{Na}_{2}$-EDTA (Disodium-ethylenediaminetetra-aceticacid) 溶液作製およびその注入

$\mathrm{Na}_{2}$-EDTA（以下 EDTA と略す）粉末を $5 \%$ ブドウ 糖液に溶解させ，それぞれ $2 ， 2.5 ， 3 ， 4$ 扎よび $8 \%$ 溶 液とし滅菌して用いた．その注入は 1 分間 $1 \mathrm{ml}$ の一定 した量で原則として心停止に至るまでである．ただし， $3 \%$ 以下では約 4 時間までの注入である.

\section{3. 可 検 材 料}

血 漿: EDTA 注入前と注入後は心停止末で $4 \%$ 以 下では原則として 15 分, $8 \%$ では 5 分間隔で約 $3 \mathrm{~m} l$ ず つ採血し血漿分離した。
低 $\mathrm{Ca}$ 血症飞関する研究

脊髄液：4\%注入群中 4 例（Nos $4 \sim 7 ）$ と $8 \%$ 中 5 例 (Nos 11〜 15) の計 9 例については整死時の 1 回だけで あるが, No. 7 と 14 の 2 例は注入前と斃死時の 2 回に かけ腰椎穿刺により約 $1 \mathrm{ml}$ ずつ採取した.

組 織: EDTA 注入による整死直後, ただらに解体 して検体を採取した $4 \%$ 注入群中 4 例（Nos 5，7～9)， $8 \%$ 中 6 例（Nos 11〜16）の計 10 例である.

対照としては放血による殺後直ちに採取したもの(No. 17）を用いた。採取した組織は大脳皮質, 小脳皮質, 腎 蔵皮質, 心臓, 肝蔵および骨格筋である. 骨格筋は大腿 直筋と腓腹筋である. $4 \%$ 注入群中 1 例 (No. 7) は注 入直前と注入後 60 分, 90 分乱よび 120 分（整死直後）の 4 回にわたり大腿直筋から，8\%注入群中 2 例(Nos 15, 16）も同じく注入直前と注入後 30 分括よび整死直後の 3 回外科的処置により同時に大脳皮質と大腿直筋からの経 時的採取を行なった. 筋肉からは約 $1 \mathrm{mg}$, 大脳皮質か らは約 $200 \mathrm{mg}$ 大である.

\section{4. カルシウム $(\mathbf{C a})$ 濃 度の測 定}

血中 $\mathrm{Ca}:$ キレート $\mathrm{Ca}$ 执よび非キレート $\mathrm{Ca}$ の和を 便宜上血漿総 Ca といい, TRUdEAU and FREIER ${ }^{18)}$ の方 法の変法で日立 208 型原子吸光光度計を用いて測定した (以下原子吸光法と略す).

いっぽう, 非キレート $\mathrm{Ca}$ (以下血漿 $\mathrm{Ca}$ と略す) は GITELMAN らの方法 ${ }^{4}, 6$ ) (以下 OCPC 法と略す) にした がって日立 139 型分光光度計を用いて測定した。

脊䯣液中 $\mathbf{C a}$ : 憼死後あるいは殺後ただちに採取した 材料は表面の血液を可及的完全に除き, 各組織とも注 一定の部位で約 30〜100 mg の検体を採取し，あらか じめ脱鉄処理した石英試験管に入れ湿重量を計った後, $105^{\circ} \mathrm{C}$ の定温乾燥器内に 24 時間乾燥させ, 3 回以上そ の重量を計ってその差が $0.1 \%$ 以下になったときの重量 を乾燥重量とした. ついで, $550^{\circ} \mathrm{C}$ の電気蠦に入れて完 全に灰火させたのち， $0.5 \mathrm{ml}$ の濃塩酸で溶出させてか $5 \mathrm{SrCl}_{2}$ と $\mathrm{Na}_{2}-\mathrm{EDTA}$ の同量混合液で希釈し, この検 体中の $\mathrm{Ca}$ 量を原子吸光法で測定して乾燥重量 $\mathrm{kg}$ 当た りの量 $(\mathrm{mM})$ に換算したものを組織濃度として表わし た.

\section{5. そ の 他}

PCV (\%), 反射 (対光, 角膜, 眼瞼おょび肛門) 機 能検査, また臨床症状の発現などの観察を同時に行なっ た.

\section{結果}

\section{EDTA 溶液注入時における臨床症状}

$2,2.5$ 和よび $3 \%$ 濃度の注入では大差なくほとんど が注入後約 90 分で $7 \mathrm{mg} / 100 \mathrm{~m} l$ 前後に低下し, 呼吸数 の増加, 各種反射の減弱や体温の低下などが現われたが, その後の症状の進行は徐々であって起立不能のような重 
姜

篤な症状は示さなかった.この場合の血漿 $\mathrm{Ca}$ 濃度の低 下は非常に緩慢で $4 \mathrm{mg} / 100 \mathrm{~m} l$ 以上にとどまっていた.

$4 \%$ \%゙は個体により若干の違いはあったが， 5〜 6mg/ $100 \mathrm{ml}$ で前述した軽い低 $\mathrm{Ca}$ 血症の症状が現われてき た. 3〜 $4 \mathrm{mg} / 100 \mathrm{ml}$ で は後監の脱力をきたし坐り込む よらになってきた。この時点では対光反射をはじめ各種 反射の減弱が明らかであり, 体温は注入前に比べ $1^{\circ} \mathrm{C}$ 前 後低くなっていたが，肛門反射は他の反射に比べやや抵 抗性を示した. $2 \mathrm{mg} / 100 \mathrm{ml}$ 以下では横卧姿勢に陥り各 種反射もほとんど消失し, それから間代性痤攣を発作し 心停止に至った。

$8 \%$ では 2 例を除き注入後 40 分以内で心停止に至っ たが, 症状の発現は, $7 \mathrm{mg} / 100 \mathrm{ml}$ 前後で注入後約 10 分 以内であった. その後の症状の進行と血漿 $\mathrm{Ca}$ 濃度の低 下は急激で, 両者の関連性は $4 \%$ 注入群に示されたはど 明らかではなかった. 心停止まで 56 分と 90 分を要し た 2 例は $4 \%$ 注入群に近い反応を示した.

\section{EDTA 溶液注入時における血中 $\mathrm{Ca}$ 濃度}

図 1 に示したように，3\%以下，4\%およ゙ $8 \%$ 注入 時の血漿 $\mathrm{Ca}$ 濃度の低下のパターンは異なっていた.

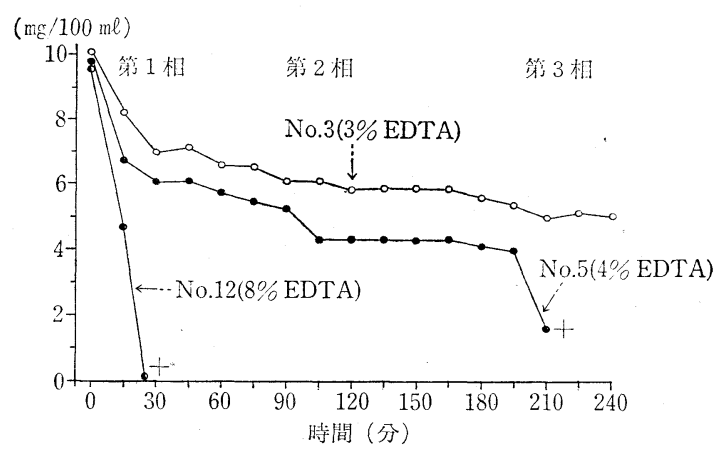

図 1 EDT A 溶液濃度差による血漿 $\mathrm{Ca}$ 濃度の変化

すなわち，3\%では30分までは血清 $\mathrm{Ca}$ は急減し，そ の後はゆるやかに $6 \mathrm{mg} / 100 \mathrm{ml}$ くらいまで下降したが, 240 分でも起立不能には至らなかった。 $4 \%$ では注入後 30分前後の間にみられた急激でほぼ直線的な低下（第 1 相), それから同じ量の注入にもかかわらず緩慢な低下 (第 2 相), その後再び急激な低下を示し(第 3 相), 死の 転機をとる時期が明らかであった（図 2).

$8 \%$ 注入では各種の変化がいずれも直線的な $\mathrm{Ca}$ 低下 の反応が強く，3\%以下では注入初期は急激な低下を示 したが，その後は緩慢な低下にとどまっていた(図1).

血漿総 $\mathrm{Ca}$ 濃度は全過程をつらじて若干の増減が見ら れ，末期には明らかに正常範用以下の低值を示す例が見 られた。

\section{3. 尙檤 液 中 $の \mathbf{C a}$ 濃 度}

整死直後の材料での OCPC 法では平均 $4.6 \pm 0.5$, 原
本好茂一

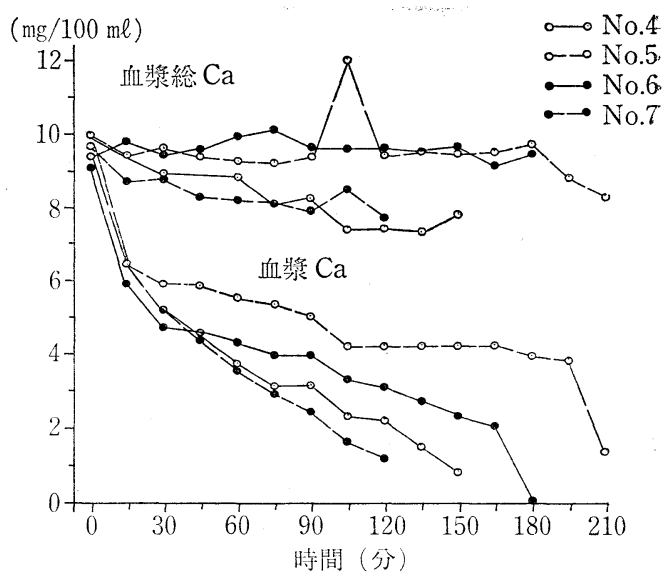

図2 $4 \%$ EDTA溶液注入時における血漿 $\mathrm{Ca}$ 濃度の変化

子吸光法では平均 $5.0 \pm 0.5 \mathrm{mg} / 100 \mathrm{ml}$ であった. 同一 個体についての EDTA 注入前と整死直後に叔いての変 動は認められなかった。

\section{4. 組 織 内 $\mathbf{C a}$ 濃 度}

表 2 に示したように, 正常では小脳皮質拉よび腎臓皮 質が高く, 骨格笳, 肝臓および心蔵のほうが低值であっ た. EDT A注入による斃死後の $4 \%$ 注入群中 4 例, 8 \%注入群中 6 例についての結果（表 2) は正常山羊に比 ベると各組織ごとに低下の程度は異なるが，両者とも低 下を示して拉り，4\%注入群がより著明であった。

表 2 正常山羊おょびEDT A 注入による死後組織 $\mathrm{Ca}$ 濃度*

\begin{tabular}{lrrr}
\hline 組 織 & 正常 $(\mathrm{n}=1)$ & $4 \%(\mathrm{n}=4)$ & $8 \%(\mathrm{n}=6)$ \\
\hline 大䏚皮質 & 10.6 & $7.5 \pm 0.9$ & $7.1 \pm 1.3$ \\
小脳皮質 & 88.8 & $68.7 \pm 10.0$ & $80.0 \pm 11.6$ \\
心 臓 & 3.8 & $2.5 \pm 0.1$ & $2.8 \pm 0.3$ \\
肝 臟 & 3.3 & $1.8 \pm 0.3$ & $2.6 \pm 0.5$ \\
腎臓皮質 & 21.4 & $20.1 \pm 9.1$ & $12.6 \pm 3.7$ \\
腓 腹 筋 & 3.4 & $2.8 \pm 0.2$ & $2.9 \pm 0.2$ \\
大腿直筋 & 3.4 & $2.8 \pm 0.1$ & $2.8 \pm 0.1$ \\
\hline
\end{tabular}

$* \mathrm{mM} / \mathrm{kg}$ : 乾燥重量 $\mathrm{n}$ : 検体数

$8 \%$ 注入群中 2 例に和いての大腿值筋および大脳皮質 に拉ける経時的変化は表 3 に示すと和りである.すなわ ち, 大腿直筋では注入後30分までの間はほとんど変化が なく，その後かなりの低下を示したが，大脳皮質では注 入後 30 分ですでに 10\% 前後の明らかな低下を示して 预り, 整死直後の低下率も大腿直筋に比べやや大きかっ た(表 3 ).

$4 \%$ 注入群中 1 例 (No. 7) の大腿直筋についての注入 前, 注入後 60 分, 90 分括よび 120 分 (整死直後) の 経時的測定での濃度はそれぞれ 3.5, 3.5,2.8, 2.6 で 


\section{山羊に打ける実験的}

表 $38 \% \mathrm{EDTA}$ 注入による $\mathrm{Ca}$ 濃度の変化

\begin{tabular}{|c|c|c|c|c|}
\hline 山羊 No. & 時間 (分) & 大㼩直筋* & 大脳皮質* & 血漿** \\
\hline \multirow{3}{*}{15} & 注入前 & 3. $6(100)$ & $9.0(100)$ & 9.2 \\
\hline & 30 & 3. $6(100)$ & $8.3(92)$ & 3.2 \\
\hline & $56 * * *$ & $3.2(89)$ & $7.6(88)$ & 1.4 \\
\hline \multirow{3}{*}{16} & 注入前 & 3. $3(100)$ & $10.7(100)$ & 7.7 \\
\hline & 30 & $3.2(97)$ & $9.4(89)$ & 1.8 \\
\hline & $45^{* * * *}$ & $3.0(89)$ & $9.3(88)$ & 0 \\
\hline
\end{tabular}

* $\mathrm{mM} / \mathrm{kg}$ 乾燥重量 ** $\mathrm{mg} / 100 \mathrm{~m} l$ *** 整死直後 （）Ca 濃度の含有量を\%として現わした

あって，そのときの血漿 $\mathrm{Ca}$ 濃度は 9.7，3.7, 2.5, 1.3 $\mathrm{mg} / 100 \mathrm{ml}$ であり, 注入後 60 分の間には大腿直筋には 変動が見られなく，末期になって明らかな低下を示し， $8 \%$ 注入群の大腿直筋での变化とまったく同様な傾向が 示された.

\section{考察}

山羊を用いて行なった実験で, 血漿 $\mathrm{Ca}$ 濃度 $6 \mathrm{mg} / 100$ $\mathrm{m} l$ 前後で症状の発現があり, $4 \mathrm{mg} / 100 \mathrm{~m} l$ 以下で姿勢崩 壞, $2 \mathrm{mg} / 100 \mathrm{ml}$ 以下では完全な起立不能の状態に陷り, その後心停止といら一連の経過功とくに $4 \%$ 注入群に共 通して認められ，これは低 $\mathrm{Ca}$ 血症牛めるいは乳熱牛の 血中濃度とほぼ一致している゚,10,13 17).

山羊に㑧ける血漿 $\mathrm{Ca}$ 濃度の変動パターンは, 基本的 には牛の実験例の報告 ${ }^{16)}$ と同じく，3 相に分けて考学る ことができよう.すなわら，注入初期の急激な低下を示

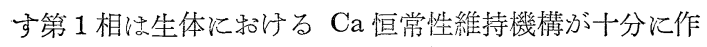
働する以前の純然たる血管内 Caだけの反応による時 期，同じ量の EDTA 注入にもかかわらず，その低下が 緩慢となる第 2 相は上記の機構が十分に作働している時 期, そして再び急激な低下を示す算 3 椙であるがその原 因としては，血管外コンパートメント内の利用可能な移 動性 Ca の涸渴が第1 亿考学ているが，それには骨和よ

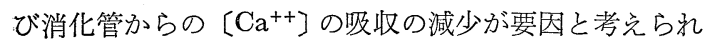
る15 17). したがって, 重篤な低 $\mathrm{Ca}$ 血症の症状を呈する

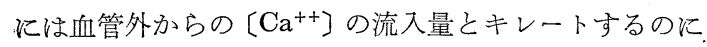
匹敵するかまたはそれ以上の EDTA 濃度の注入が必要 であることがわかる。

$4 \%$ 特よびそれ以下の低濃度注入では, 血漿 $\mathrm{Ca}$ 濃度 が $6 \mathrm{mg} / 100 \mathrm{~m} l$ 前後で症状の発現が示されたが $8 \%$ 注 入群では $7 \mathrm{mg} / 100 \mathrm{ml}$ 以上で症状の発現るみ，しかも その進行も急激であった.

このことは, 血中 $\mathrm{Ca}$ 分画のらら生理的活性を有する

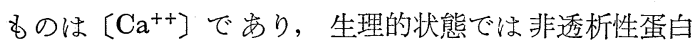
結合 $\mathrm{Ca}$ (Ca-prot) との間に一定のバランスを保ってい

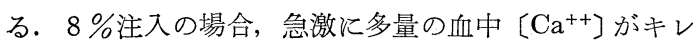

低 $\mathrm{Ca}$ 血症に関する研究

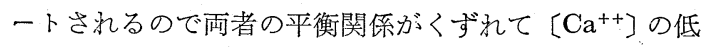
下がより顕著となり見かけ上，血漿 $\mathrm{Ca}$ 濃度は若干高く

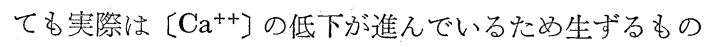
か, または急激な血中濃度の低下に対しその恒常性維持 機構が殆んど作働しないために和こるショックも考兄ら れる。

組織内 $\mathrm{Ca}$ 濃度は組織によって異なっているが，一般 的には腎臓が高く, 肝臓と骨格笳が低かったといら報告 がある ${ }^{1,8)}$. 今回の実験結果もほぼ同様な傾向を示した.

EDTA 注入により獘死した組織内濃度は対照山羊に 比べ，いずれも低值を示して和り，また組織によってそ の低下率ぶ異なることふらこの低下は単に細胞外液中の $\left[\mathrm{Ca}^{++}\right]$濃度のみならず, 細胞内液中の $\left[\mathrm{Ca}^{++}\right]$の低下 の可能性子大きい.

牛に和汗る泌乳初期には骨格筋 $\mathrm{Ca}$ の約 12〜15\% に 相当する量の低下が知られている ${ }^{17)} 3 ゙$ ，泌乳初期のよう に血中 $\mathrm{Ca}$ 濃度の急激な低下をともならときには, 細胞 外液 $\mathrm{Ca}$ 恒常性維持機構のコンパートメントの一部とし ての役割をはたしているすのと考えられ，本実験にみら れた骨格筋または他の組織内濃度の低下の意義も同様に 解される.

$4 \%$ 特よび $8 \%$ 注入時の経時的測定による骨格筋内 $\mathrm{Ca}$ 濃度は $4 \%$ 注入例で 60 分, $8 \%$ 注入例で 30 分まで 殆えど変動を示さず，比較的末期になって低下号示した が，前述の $8 \% 2$ 例に和いての大脳皮質では注入後 30 分ですでに 10\% 前後の低下を示し，末期に晾ける低下 率当骨格筋よりやや大きかった。 このことから, 血中 $\mathrm{Ca}$ 濃度の著減に対する生体反応は神経組織の法らが筋 組織よりも早い時点で起こることが認めらひた。すなわ ち, 血漿 $\mathrm{Ca}$ の低下にともなって, 中枢神経機能に分類 される対光, 角膜初よび眼瞼反射の漸進的な減弱, 体温 の低下，姿勢崩壞の様式，めるいは神経性の反応を裏づ ける間代性痤攣発作の出現などの臨床所見の推移とるよ く符合するものであって, 中枢神経細胞内に郝ける〔Ca ++了の生化学的機序の解明を要する点が少なくないが, 以上のことから低 $\mathrm{Ca}$ 血症時にともなら症状の発現は中 枢神経系の機能障害による可能性が大さいるのと考觉ら れる。

\section{要 約}

山羊に各種濃度の EDTA 溶液注入による低 $\mathrm{Ca}$ 血症 の発症実験を行なった結果，つぎのような成績が得られ た.

1） $4 \%$ 物よび $8 \%$ EDTA 溶液注入では，いずれも 低 $\mathrm{Ca}$ 血症から起立不能新よび心停止までの経過をたど ったが， $8 \%$ 注入群では $4 \%$ 注入群汪ど血中 $\mathrm{Ca}$ 濃度と 症状の進行は明らかではなかった。

2) $2 \%, 2.5 \%$ 和よび $3 \%$ EDTA 溶液の約 4 時間注 
入では, 典型的な低 $\mathrm{Ca}$ 血症の発症には至らなかった。

3） EDTA 溶液注入による敬死後の組織内 $\mathrm{Ca}$ 濃度 は, 対照山羊に比べていずれも低值を示した。

4）神経組織（大脳皮質）和よび筋組織（大腿直筋） に和ける経時的分析では，前者のほらが後者より先に低 下を示して括り，乙かもその低下率が大きいことが認め られた。

以上のよらなことから，低 $\mathrm{Ca}$ 血症にともなら症状の 発現には, 中枢神経系の機能障害により生ずる可能性が あるものと推測される.

$$
\text { 文献 }
$$

1) Bianchi, C.P.: Cell calcium, London, England, Butterworth (1968).

2) Boda, J.M. and Cole, H.H.: J. Dai. Sci., 37, $360 \sim 372$ (1954).

3) Bowen, J.M., Blackmon, D.M. and Heavner, J.E.: Amer. J. vet. Res., 31,831 839 (1970).

4) Connerty, H.V. and Briggs, A.R.: Amer. J. Clin. Path., 45,290 296 (1966).

5) Curry, D.L., Bennett, L.L. and Grodsky, G. M.: Amer. J. Physiol., 214,174 177 (1968).

6) Gitelman, H.J.: Anal. Biochem., 18,521 531 (1967).

7) Gittes, R.F., Toverud, S.U. and Copper, C.W.: Endocrinol., 82, 83 90 (1968).

8) Kowalczyk, D.F. and Mayer, G.P.: Amer. J.
Vet. Res., 33,751 757 (1972).

9) Kronfeld, D.S. and Ramberg, C.F.: Bovine Medicine \& Surgery, W.J. Gibbons, E.J. Сатсотт, and J.F. Smithcors, editors, pp. 382 394, Illinois, American Veterinary Publications (1970).

10) Little, W.L. and Wright, N.C.: Brit. J. Exp. Pathol., 6,129 134 (1925).

11) Littledike, E.T., Whipp, S.C., Witzel, D.A. and Baetz, A.L.: Parturient Hypocalcemia, J.J.B. ANDERson, editor, pp. 165 176, New York, Academic Press (1970).

12) Nayer, G.P., Ramberg, C.F. and Kronfeld, D.S.: J. Nutr., 92, 253 260 (1967).

13) Mayer, G.P., Ramberg, C.F., Kronfeld, D.S., Buckle, R.M., Sherwood, L.M., Aurbach, G. D. and Potts, J.T.: Amer. J. Vet. Res., 30,1587 1597 (1969).

14) Moodie, E.W. and Robertson, A.: Res. Vet. Sci., 3,470 484 (1962).

15) Payne, J.M.: Vet. Rec., 76,77 80 (1964).

16) Ramberg, C.F., Mayer, G.P., Kronfeld, D.S., Aurbach, G.D., Sherwood, L.M. and Potts, J.T.: Amer. J. Physiol., 213,878 882 (1967).

17) Sмith, V.R. and Brown, W.H.: J. Dai. Sci., 46,223 226 (1963).

18) Trudeau, D.L. and Freier, E.F.: Clin. Chemist., $13,101 \sim 114$ (1967).

\section{<海外文献要録 $>$}

初乳未摂取の新生仔牛に打消化管大腸菌症の病理発生について G.R. Pearsor \& E.F. Logan : Vet. Rec., 105, 159 164 (1979).

7 頭の新生仔牛に経口的に病原性の E. coli 0101K? (A) を接種し，剖検した． 全例に执いて細菌の小腸粘膜への 付着が認められた.

接種後 3 時間では小腸末端に若干の菌がみられるにす ぎないが，6〜36 時間では次第に菌の付着がみられるよ らになった.
病理変化は接種後 6 12 時間に 発現し, 䋐毛は短縮 し，肥厚し，上皮表面は不規則となることが判明した. 下痢などの症状が発現する数時間前にすでに病原菌の定 着がみられ，これは菌侵入後值ちに成立する。したがっ て, 菌定着を防ぐためには初乳は菌が侵入する前に投与 して祘かなくてはならない。

\section{||||||||||| 獣 医 師 募 集 ||||||||||||}

1. $80 \%$ 小動物, $20 \%$ 大動物の診療. 将来一般小動物, 競走馬, 乳牛の専門医として独立意欲のあるも の，または当院にて永続勤務するもの.

2. 募集人員：6 名内（女子 1 名含む）※履歴書, 写真, 獣医師登録番号を提出のこと.

3. 経験者, 見習獣医師，国試再受験中を問わずファイトと誠意あるもの.

4. 給 与 等: 委細面談, 高給優遇

5. 勤 務 地 : 東京・世田谷区・世田谷病院＼cjkstart涉谷区・橴谷病院

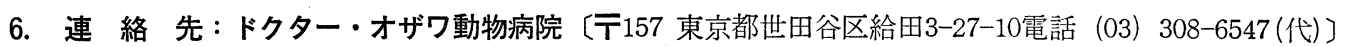

